\title{
Estimating Economic Carrying Capacity for an Ungulate Guild in Western Canada
}

\author{
Gerald W. Kuzyk ${ }^{*, 1}$, N.L. Cool ${ }^{2}$, E.W. Bork ${ }^{3}$, C. Bampfylde ${ }^{\#, 4}$, A. Franke ${ }^{\dagger, 1}$ and R.J. Hudson ${ }^{1}$ \\ ${ }^{1}$ Renewable Resources, University of Alberta, Edmonton, Alberta, T6G 2H1, Canada \\ ${ }^{2}$ Parks Canada. Elk Island National Park of Canada, Site 4, RR 1, Fort Saskatchewan, Alberta, T8L 2N7, Canada \\ ${ }^{3}$ Agricultural, Food and Nutritional Science, University of Alberta, Edmonton, Alberta, T6G 2P5, Canada \\ ${ }^{4}$ Centre for Mathematical Biology, Mathematical and Statistical Science, University of Alberta, Edmonton, Alberta, \\ T6G 2G1, Canada
}

\begin{abstract}
Elk Island National Park in western Canada provides an ideal case study for an economic carrying capacity estimate because it supports high density of four species of ungulates $\left(11 / \mathrm{km}^{2}\right)$, lacks large predators, and is enclosed by a 2.1-meter mesh fence. This high density of ungulates has created persistent management challenges by altering vegetation structure and community composition. Using linear programming, we explored optimal allocation of forage resources for bison (Bison bison bison), moose (Alces andersoni), wapiti (Cervus elaphus manitobensis) and deer (Odocoileus virginianus and $O$. hemionus) to maximize ungulate biomass and numbers, when constrained by use of the major forage classes and minimum viable populations (MVP) of those ungulate species that do not cross the boundary fence (bison and wapiti). Maximum numbers of animals were achieved by a stocking combination dominated by deer and bison, whereas maximum biomass was attained when bison and moose were abundant but deer were absent. Wapiti remained at MVP during all solutions. Optimal solutions consistent with current ungulate densities were associated with 7 to $11 \%$ forage removal. This is less than normally assumed for sustainable forage use, and may reflect the need to account for other biotic and abiotic losses to forage in carrying capacity models for which ungulate densities can be constrained by availability of a preferred forage class (e.g., grass) as well as forage quality. This research extends the conventional animal-unit concept to multispecies systems and provides templates based on forage biomass allocation for resource managers facing similar problems of joint stocking in different environments.
\end{abstract}

\section{INTRODUCTION}

Determining the number of herbivores a land base can sustain presents a persistent challenge particularly in multispecies grazing systems [1-5]. This sustained stocking rate is commonly termed carrying capacity $[6,7]$ and is used as a metric to balance ecological, economic, and aesthetic concerns [8-11]. In practice, carrying capacity is rarely measured [12] and initial estimates are progressively adjusted in adaptive management programs. In addition, the term "carrying capacity" is used in numerous ways, adding to the complexity of the problem $[6,13]$.

Ecological carrying capacity $(\mathrm{K})$ is usually defined as the maximum number of animals a defined area can support in relation to available resources [14], where $\mathrm{K}$ is primarily limited by forage [6,7]. Population biologists define ecological $\mathrm{K}$ as an equilibrium at which population growth rate equals zero $[6,15]$. This differs from economic $\mathrm{K}$, which prescribes stocking rates in relation to available vegetation

*Address correspondence to this author at the Ministry of Environment, Wildlife Science Section, P.O. Box 9338 Stn Prov Govt, Victoria, BC, V8W 9M1, Canada; Tel: +1 2503875842; Fax: +1 2503569145;

E-mail: gerald.kuzyk@gov.bc.ca

${ }^{\#}$ Current address: Alberta Environment, Government of Alberta, Edmonton, Alberta, T5J 1G4, Canada.

${ }^{\dagger}$ Canadian Circumpolar Institute, University of Alberta, 1-42 Pembina Hall, Edmonton, Alberta, T6G 2H8, Canada.
[6] that achieve sustained productivity and profitability $[2,16]$. Range managers use economic $\mathrm{K}$ to maximize stocking rates without degrading forage quantity or quality or altering plant community succession in undesirable ways $[6,17]$.

Solutions are constrained first by plant removal rates and safe-use factors (SUF) where forage removal by native ungulates is commonly set between $35-50 \%$ of annual growth to allow for variation in forage availability [18-20]. The forage reserve (i.e., the proportion of the forage remaining) may be used to provide a buffer against stochastic environmental conditions and prevent degradation of vegetation during years with unfavorable growing conditions [21]. In strongly seasonal environments, another hedge provided by the forage reserve is sufficient opportunity for diet selection to meet seasonal quality thresholds. Although range scientists and managers frequently use various vegetative measures of range condition to ensure long-term sustainability [22,23], criteria for evaluating appropriate stocking levels seldom include measures related to the animals present in the system [24,25].

Reliable estimates of the daily dry matter intake by ungulates are central to assessing carrying capacity and determining animal unit equivalents [22,26]. In a multi-species system, dry matter intake varies among species, but can be generalized from their digestive capacity and body size [27]. 
Large ungulates are generally bulk feeders that consume large amounts of low quality grass [28], whereas smaller ungulates are concentrate selectors and consume smaller quantities of highly digestible forage such as forbs or browse $[29,30]$. Medium-sized ungulates are often intermediate feeders and consume varying proportions of shrubs and grass [31].

Forage demand can be measured as the amount of forage consumed per day and is often standardized as animal-units [2]. One animal-unit is usually considered to be the body mass equivalent of one domestic cow either with a calf less than 6 months old $(454 \mathrm{~kg})$ or without a calf. One animal unit is assumed to require $26 \mathrm{~kg}$ of forage (based on air-dried weight) per day [2,22]. One animal-unit month is defined as the sum of the daily requirements accumulated over one month or approximately $780 \mathrm{~kg}$ of forage [32]. Perhaps because of its simplicity, the animal-unit concept has been widely adopted by range managers concerned with grazing livestock that are either similar in dietary preferences or graze pastures with little opportunity for selection [2,33]. However, there are difficulties extending the animal-unit concept to wild ungulates in heterogeneous environments [22,34].

In contrast to seasonal livestock grazing, requirements for wild ungulates require forage to be characterized at the scale of an "animal-unit-year" as they remain present on the landscape over a full twelve-month period without supplementation. Furthermore, despite assigning a value of anticipated forage removal for each ungulate species [22], forage specialization of wild ungulates and seasonal shifts in diet [35-37] preclude forage use estimates at the scale of the animal-unit month. As such, monthly or seasonal diets and intakes of wild ungulates are summed to annual totals. Lastly, despite the fact that most wild ungulates co-exist in multispecies systems [38-41], there is limited information associated with concurrent daily intakes of sympatric species $[22,42]$.

Elk Island National Park (EINP) is a small, enclosed and carefully monitored park $\left(194 \mathrm{~km}^{2}\right)$ in western Canada that provides an ideal opportunity to explore the concept of economic carrying capacity. The park supports four species of ungulates and is a relatively controlled environment due to the lack of predators and complete enclosure of the park by a 2.1-m page wire fence. Because of the lack of predators and the presence of the fence, resource managers are forced to manage ungulate numbers relative to the available vegetation. The fence contains plains bison, wood bison and wapiti, but allows movement of moose, white-tailed deer and mule deer [43]. The ungulate guild within the park approaches the biomass and productivity of multi-species grazing systems of East Africa [44]. Because the density of ungulates is high $\left(11 / \mathrm{km}^{2}\right)$, the range area is small, and the movements of ungulates are relatively fine-scale [45], carrying capacity calculations must be based on forage allocation.

Linear programming is generally used to determine an optimal combination given a set of decision variables that are subject to one or more constraints, and has been used routinely for solving resource allocation problems [46,47]. Others have used linear programming in range management $[20,48,49]$ as well as for other wildlife and plant-related questions with varying degrees of success. For example, Hastings et al. [50] used linear programming to determine the optimal age or stage class to control invasive plant species under the constraints of time and financial budget. Belovsky [51] used linear programming to examine optimal summer diet of moose. Because plants vary in nutrient qual-

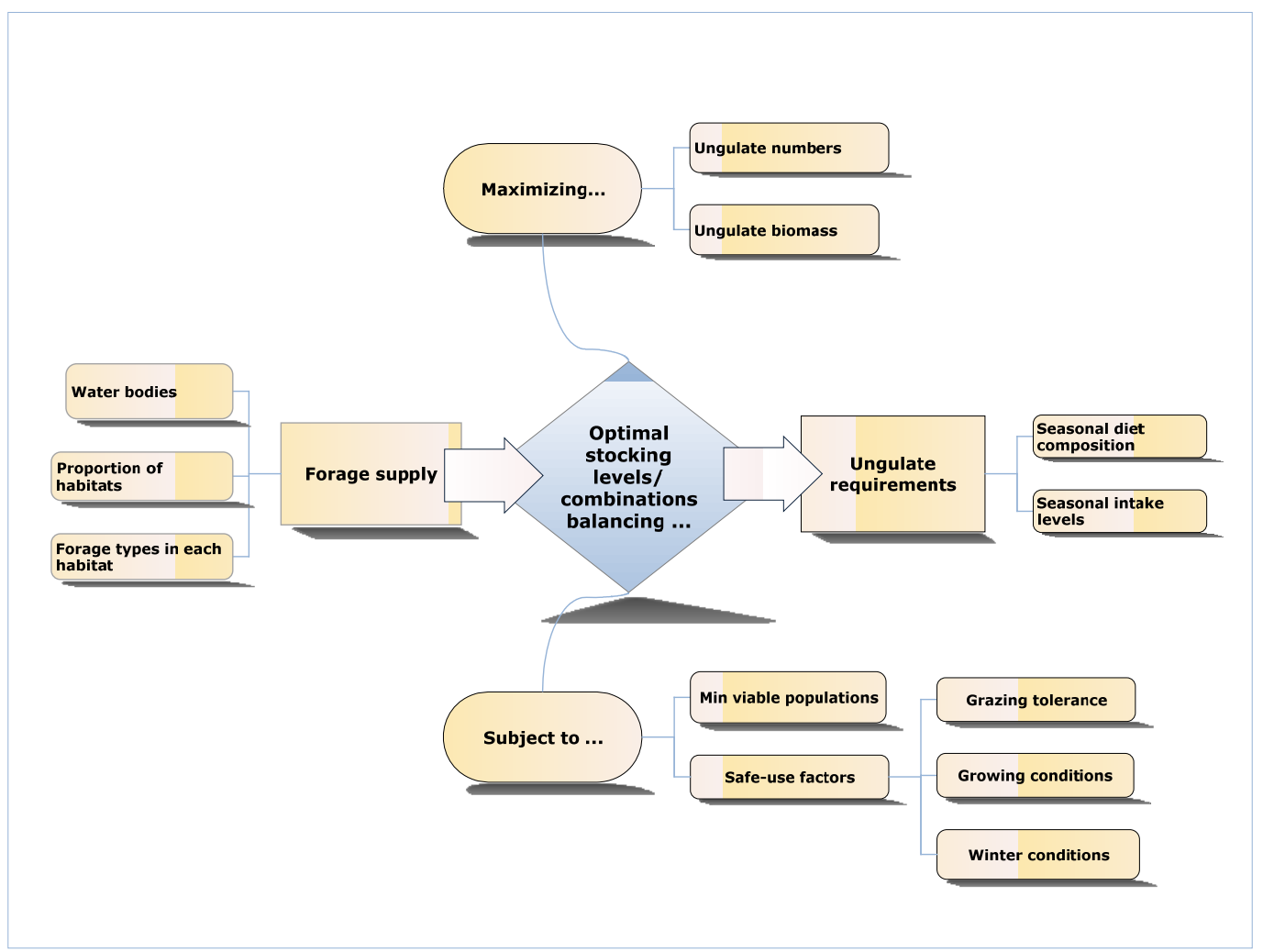

Fig. (1). Aggregate forage supply and demand factors for ungulates in fall of 2006 in Elk Island National Park, Alberta. 
ity, it was assumed that a varied diet selection was required to produce an optimal diet of energy-rich but sodium-poor terrestrial plants, combined with energy-poor and sodiumrich aquatic plants. Belovsky [51] determined optimal diet was constrained by 1) energy, 2) sodium content, and 3) rumen size. Hobbs [52] later contested Belovsky's approach with specific criticisms of digestive constraints and questioned the high success of predictability. Although Belovsky's formulation has been criticized as inappropriate for testing the optimal foraging theory [51,52], this is not an indictment of linear programming as a method that has been used successfully to examine forage allocation across a guild of ungulates. Irby et al. [20] used linear programming to find solutions for the optimal allocation of available forage to multiple ungulates in Theodore Roosevelt National Park, North Dakota.

The objective of our research was to develop a protocol and a template for an annual estimate of economic carrying capacity for bison, moose, wapiti, and deer in the Main Park $\left(134 \mathrm{~km}^{2}\right)$ of EINP (Fig. 1). Linear programming was used to calculate optimal solutions for the maximum number and the maximum biomass of ungulates given pre-set management constraints (sustainable use of park vegetation and minimum viable populations of bison and wapiti). An animal-unit-year approach was used by matching annual forage supply $(\mathrm{kg} / \mathrm{ha}$ of grass, forbs, shrubs across four primary habitats) with the corresponding ungulate demand estimated from seasonal diets and intakes summed annually ( $\mathrm{kg}$ forage per ungulate per year). Feasible solutions require that resources last for one full year, so solutions with seasonal shortfalls are excluded. This approach applies the principle of economic carrying capacity to evaluate an application for resource management and is not validated against forage utilization estimates.

Linear programming as applied here requires that the proportion of total forage used annually be set as one of the initial input variables. Therefore, given any proportion of total annual forage used, an estimate of the annual forage supply, an estimate of the total ungulate demand, and an appropriate model structure, the optimal combination of bison, moose, wapiti and deer in biomass, abundance or other measure of value can be calculated. Finally, known densities of ungulates in the park (December 2006) were compared to the optimal stocking solutions reported at each level (total annual forage used) tested. These solutions can be viewed as initial estimates of economic carrying capacity for the ungulate guild and provide insights and a starting point for determining economic carrying capacity and resource management strategies.

\section{MATERIALS AND METHODOLOGY}

The Main Park (hereafter - Park) of EINP was used to allow comparison with the similar work done in the same area [44]. EINP is located in the Beaver Hills approximately $40 \mathrm{~km}$ east of Edmonton, Alberta, Canada (53 $36^{\prime} \mathrm{N}$ and $112^{\circ} 51^{\prime} \mathrm{W}$ ) (Fig. 2). The park is part of the Cooking Lake moraine at elevations $30-60 \mathrm{~m}$ above surrounding areas and has several shallow lakes. The park is surrounded mostly by agricultural land and has a four-lane highway (Highway 16) bisecting the park into the Main Park on the north side (134 $\left.\mathrm{km}^{2}\right)$ and the Wood Bison Isolation Area $\left(60 \mathrm{~km}^{2}\right)$ on the south side. The climate is characterized by cold winters and warm summers with mean temperatures of $-14^{\circ} \mathrm{C}$ in December and $16^{\circ} \mathrm{C}$ in July. Annual rainfall precipitation is 496 $\mathrm{mm}$, of which $375 \mathrm{~mm}$ falls as rain and $121 \mathrm{~mm}$ as snow [53].

Moose, wapiti, white-tailed deer and mule deer occur throughout the park, but plains bison are restricted to the Main Park and wood bison to the Isolation Area. In December 2006, 476 plains bison, 72 moose, 333 wapiti and 78 deer inhabited the Main Park [54]. Minimum viable populations (MVP) are maintained at pre-calving populations of 175 bison and 350 wapiti [55]. Historically, wolves, grizzly

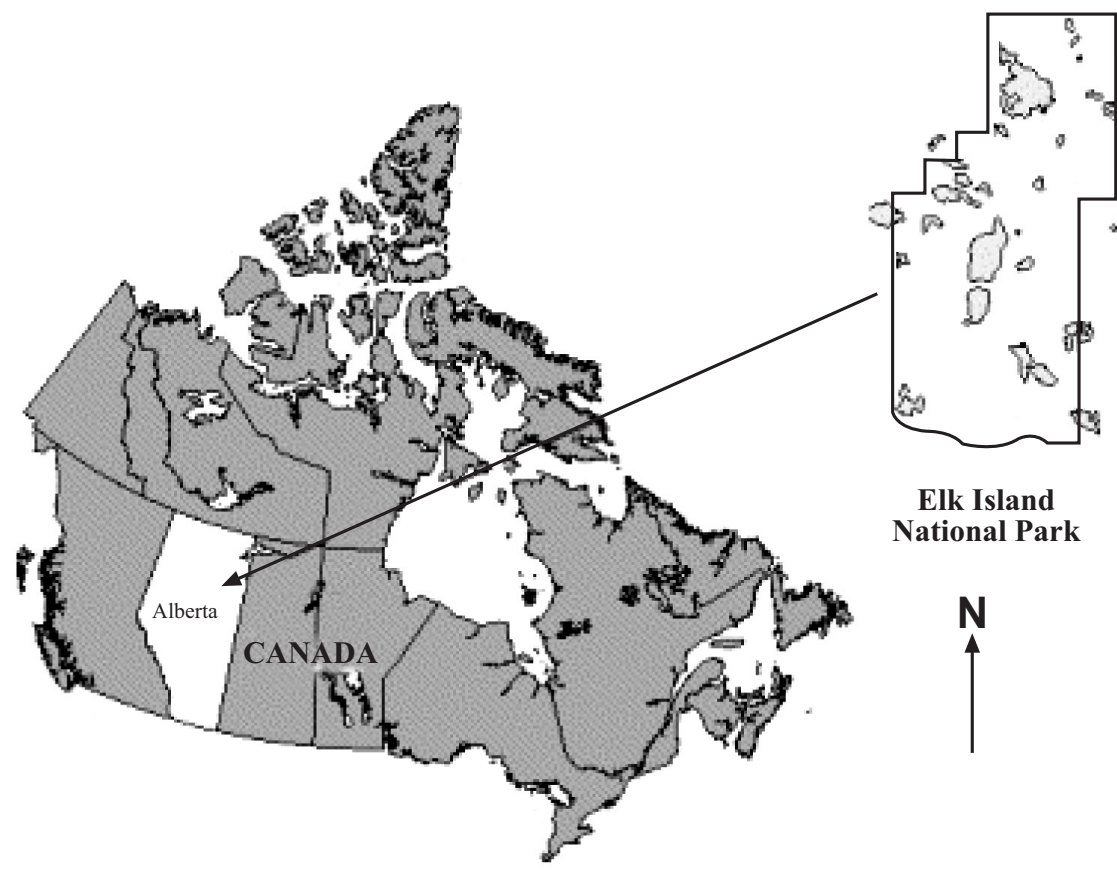

Fig. (2). Location of Elk Island National Park in central Alberta, Canada (Map courtesy of Parks Canada). 
bears (Ursus arctos), and black bears (Ursus americanus) occupied the area, but today coyotes (Canis latrans) and lynx (Lynx canadensis) are the largest predators, with cougars (Felis concolor) [56] and black bears occasionally recorded. Beaver (Castor canadensis) are abundant and influence water levels and plant succession adjacent to wetlands [57].

EINP exists in a transitional zone between the prairie and boreal forest with vegetation classified as dry mixedwood boreal forest [21]. Trembling aspen (Populus tremuloides) is the dominant tree species and commonly co-exists with balsam poplar (Populus trichocarpa) or white birch (Betula papyrifera), with additional small areas of white spruce (Picea glauca) and black spruce (Picea mariana) in the northern part of the park. Shrub understories consist of beaked hazel (Corylus cornuta), dogwood (Cornus stolonifera), chokecherry (Prunus virginiana), willow (Salix spp.), prickly rose (Rosa acicularis), raspberry (Rubus spp.) and other shrubs. Common native grasses are Agropyron spp., Elymus innovatus and Oryzopsis asperifolia, with introduced species being Trifolium spp., Bromus spp. and Poa spp., whereas wet meadows are dominated by Calamagrostis canadensis and hydric Carex spp. often with an overstory of Salix spp. [58]. Vegetation composition is further described by Bork et al. [59,60] and Hood et al. [57].

Although the linear programming framework is deterministic, it can be used to solve complex resource allocation problems such as allocating a limited forage supply to a guild of ungulate species. We used the Microsoft Excel( linear programming "Add-In" (i.e., Microsoft Excel Solver (C). The objective function dictated how the ungulate guild (i.e., bison, moose, wapiti, deer) could be optimized to achieve 1) maximum number of individuals (animals/ha) and 2) maximum biomass $(\mathrm{kg} / \mathrm{ha})$ under the constraints of forage availability and minimum viable populations for species where this is a concern (i.e., bison and wapiti) (Fig. 1).

The two main assumptions in linear programming are (1) the objective function $(Z)$ is a linear function, $f$, of the decision variables, $\mathrm{x}_{1}, \mathrm{x}_{2}, \mathrm{x}_{3}$ and $\mathrm{x}_{4}$, and is of the form $\mathrm{Z}=\mathrm{f}\left(\mathrm{x}_{1}\right.$, $\mathrm{x}_{2}, \mathrm{x}_{3}, \mathrm{x}_{4}$ ) and (2) all variables (e.g., densities) are nonnegative or more formally, all $\mathrm{x}_{1}, \mathrm{x}_{2}, \mathrm{x}_{3}, \mathrm{x}_{4} \geq 0$.

Thus, for maximum number of individuals (animals/ha):

$\mathrm{Z}=\mathrm{c}\left(\mathrm{x}_{1}+\mathrm{x}_{2}+\mathrm{x}_{3}+\mathrm{x}_{4}\right)$,

where,

$\mathrm{c}=$ area of park $(13,400 \mathrm{ha})$ $\mathrm{x}_{1}=$ bison density, $\mathrm{x}_{2}=$ moose density, $\mathrm{x}_{3}=$ wapiti density, $\mathrm{x}_{4}$ $=$ deer density.

For maximum biomass $(\mathrm{kg} / \mathrm{ha})$ :

$\mathrm{Z}=\mathrm{c}_{1} \mathrm{x}_{1}+\mathrm{c}_{2} \mathrm{x}_{2}+\mathrm{c}_{3} \mathrm{x}_{3}+\mathrm{c}_{4} \mathrm{x}_{4}$,

where,

$\mathrm{c}_{1}=$ biomass $/$ bison, $\mathrm{c}_{2}=$ biomass $/$ moose, $\mathrm{c}_{3}=$ biomass $/ \mathrm{wapiti}$, $\mathrm{c}_{4}=$ biomass $/$ deer

$\mathrm{x}_{1}=$ bison density, $\mathrm{x}_{2}=$ moose density, $\mathrm{x}_{3}=$ wapiti density, $\mathrm{x}_{4}$ $=$ deer density.

In addition, genetic constraints were added to ensure minimum viable populations for bison $\left(\mathrm{x}_{1}\right)$ and wapiti $\left(\mathrm{x}_{3}\right)$ where:

$\mathrm{x}_{1} \geq 0.01$ animals/ha

$\mathrm{x}_{3} \geq 0.03$ animals/ha

Forage supply was estimated using annual production of three forage classes (grass, forbs, shrubs) across four habitat types, and subsequently matched with the annual dietary preferences and forage intake levels of each ungulate species $[20,48,49]$. A forage "production by habitat" availability matrix summarized forage biomass within each of the four major habitat types of EINP (Table 1). A Geographic Information System was used to calculate the area of each habitat type based on the 1995 Alberta Vegetation Inventory coverage with refinements based on expert knowledge of the park (N. Cool, Parks Canada, Environmental Resource Conservation, personal observation) to adjust for current differences in wetland coverage (Table 1). EINP does not have a complete inventory of grass, forb and shrub forage biomass $(\mathrm{kg} / \mathrm{ha})$ for each of the four predominant habitats. Consequently, published sources from EINP were used for grass biomass for two habitat categories [61], an unpublished data set from EINP for grass, forb and shrub values for aspen habitats [62], with the remaining values taken from data compiled across the dry and central mixedwood subregions of Alberta [21,63] (Table 1).

For each ungulate species, forage intake $(\mathrm{kg} / \mathrm{d})$ and $\%$ forage class in the diet from the four seasons were summed to annual totals (Table 2). Data on seasonal diet proportions for all species and seasons specific to EINP were used [6468] with the exception of the fall diet of bison [69], summer and fall diets of moose [66] and mule deer [69], which were taken from study areas in aspen parklands within $150 \mathrm{~km}$ of EINP (Table 2).

Table 1. Estimate of Forage Production (kg/ha) Within Each of Four Primary Habitats in Elk Island National Park, Alberta

\begin{tabular}{|l|c|c|c|c|c|}
\hline Habitat Classification & Area $(\%$ total $)$ & Grass & Forb & Shrub & Total \\
\hline \hline Aspen/balsam popular upland & 0.60 & $247^{\mathrm{a}}$ & $399^{\mathrm{a}}$ & $1053^{\mathrm{a}}$ & 1699 \\
\hline Upland grass/shrub & 0.17 & $3120^{\mathrm{b}}$ & $746^{\mathrm{c}}$ & $86^{\mathrm{c}}$ & 3952 \\
\hline Wetland sedge/shrub & 0.10 & $6053^{\mathrm{b}}$ & $470^{\mathrm{c}}$ & $11^{\mathrm{c}}$ & 6534 \\
\hline Coniferous mixedwood & 0.02 & $9^{\mathrm{c}}$ & $185^{\mathrm{c}}$ & $461^{\mathrm{c}}$ & 655 \\
\hline Water & 0.11 & - & - & - \\
\hline Total forage & & 1284 & 417 & 657 & 2358 \\
\hline
\end{tabular}

${ }^{\mathrm{a}}[62],{ }^{\mathrm{b}}[61],{ }^{\mathrm{c}}[21]$. 
Table 2. Diet Composition and Total Annual Intakes of Major Forage Classes for One Individual for Each of Four Ungulate Species in the Aspen Boreal Forest Zone of Alberta

\begin{tabular}{|c|c|c|c|c|c|c|c|c|c|c|c|c|c|c|c|c|}
\hline & \multicolumn{3}{|c|}{ Spring (\% diet) } & \multicolumn{3}{|c|}{ Summer (\% diet) } & \multicolumn{3}{|c|}{ Fall (\% diet) } & \multicolumn{3}{|c|}{ Winter (\% diet) } & \multicolumn{4}{|c|}{ * Total Annual Intake $(\mathrm{kg} / \mathrm{hd} / \mathrm{yr})$} \\
\hline & Grass & Forb & Shrub & Grass & Forb & Shrub & Grass & Forb & Shrub & Grass & Forb & Shrub & Grass & Forb & Shrub & Total \\
\hline Bison & $96^{\mathrm{a}}$ & $4^{\mathrm{a}}$ & $0^{\mathrm{a}}$ & $75^{\mathrm{b}}$ & $25^{\mathrm{b}}$ & $0^{\mathrm{b}}$ & $98^{\mathrm{c}}$ & $1^{\mathrm{c}}$ & $1^{\mathrm{c}}$ & $96^{\mathrm{a}}$ & $0^{\mathrm{a}}$ & $4^{\mathrm{a}}$ & 3454 & 304 & 38 & 3796 \\
\hline Moose & $0^{\mathrm{e}}$ & $2^{\mathrm{e}}$ & $98^{\mathrm{e}}$ & $1^{\mathrm{d}}$ & $47^{\mathrm{d}}$ & $52^{\mathrm{d}}$ & $12^{\mathrm{d}}$ & $0^{\mathrm{d}}$ & $88^{\mathrm{d}}$ & $3^{\text {ae }}$ & $6^{\mathrm{ae}}$ & $91^{\text {ae }}$ & 145 & 506 & 2963 & 3614 \\
\hline Wapiti & $92^{\mathrm{a}}$ & $3^{\mathrm{a}}$ & $5^{\mathrm{a}}$ & $8^{\mathrm{e}}$ & $25^{\mathrm{e}}$ & $67^{\mathrm{e}}$ & $64^{\mathrm{e}}$ & $3^{\mathrm{e}}$ & $33^{\mathrm{e}}$ & $38^{\mathrm{ae}}$ & $4^{\text {ae }}$ & $58^{\mathrm{ae}}$ & 1259 & 227 & 1033 & 2519 \\
\hline Deer & $94^{\mathrm{a}}$ & $1^{\mathrm{a}}$ & $5^{\mathrm{a}}$ & $36^{\mathrm{c}}$ & $7^{\mathrm{c}}$ & $57^{\mathrm{c}}$ & $51^{\mathrm{c}}$ & $6^{\mathrm{c}}$ & $43^{c}$ & $23^{a f}$ & $4^{\text {af }}$ & $73^{\text {af }}$ & 420 & 42 & 378 & 840 \\
\hline
\end{tabular}

"kg/hd/yr = (mean annual diet $\mathrm{x}$ daily forage intake $\mathrm{x}$ head $\mathrm{x} 1$ year $)$

${ }^{\mathrm{a}}[65]$.

b $[64]$.

[69].

d $[66]$

${ }^{\mathrm{e}}[67]$.

Forage intake rates of each species also were taken from nearby studies. Because a complete set of seasonal forage intake rates were lacking for all species, mean summer and fall intake rates for bison (10.4 kg/day) and mule deer $(2.3$ $\mathrm{kg}$ /day), fall intake rates for wapiti $(6.9 \mathrm{~kg} /$ day $)[34,70]$ and annual intake rates for moose (9.9 kg/day) [71] (Table 2) were used.

Mass measurements of male and female bison, wapiti and moose were taken from growth curves fit to data collected at EINP [72]. Weights of white-tailed deer were obtained from field-dressed animals taken within 150 kilometers of EINP [73] and converted to whole animal mass measures [74]. Gender ratios were assumed to be 50:50, giving annual average mass estimates of $615 \mathrm{~kg}$ for bison, $450 \mathrm{~kg}$ for moose, $350 \mathrm{~kg}$ for wapiti and $87 \mathrm{~kg}$ for deer.

Optimal combinations of ungulate numbers and ungulate biomass were compared to those in the park gathered from aerial surveys in December 2006 when there was snow on the ground and a lack of leaves on trees to maximize visibility [54]. The analysis was repeated using grass and forbs set at a constant level, and shrubs set at $60 \%$ utilization due to their noted resilience to herbivory [44] as we reasoned that availability of shrubs to browsing ungulates would be less impeded by snow [75]. The model solutions of optimal com- binations of ungulates have an associated annual forage use for the ungulate guild, which can be used as a measure of economic carrying capacity, and thus presents opportunities for insight into carrying capacity estimates for sympatric ungulates and ungulate management options for the park.

\section{RESULTS}

Calculations were conducted with the objective of achieving maximum animal numbers in the park, for example, to maximize viewing potential. In this scenario, individuals of all ungulate species were assumed to be of equal value. In other words, a visitor viewing wildlife in the park gained no additional value of seeing one species over another. On the basis of the species-specific forage rates partitioned across the available forage types, and a habitat classification of EINP, our analysis (972 animals) best matched the actual number of animals (959) recorded in EINP in 1996 when forage use was set to $7 \%$ (Table 3). This result is insightful given safe-use factors (SUF) for forage removal by native ungulates is commonly set between $35-50 \%$ of annual growth $[18,20,22]$.

The result using $7 \%$ forage use also had markedly different combinations of ungulates than occurred in EINP in December 2006 (Table 3). While 78 deer, 72 moose and 476

Table 3. Comparison of Maximum Animal Numbers Within Elk Island National Park in 2006 to Model Predictions Based on Percentage (\%) Forage Use. Forage Use is Defined as Equivalent Ratios of Grass, Forbs, and Shrubs Except when Grass and Forbs were Equivalent and Shrubs were Set at $60 \%$

\begin{tabular}{|c|c|c|c|c|c|c|c|}
\hline & \multirow[b]{2}{*}{ EINP } & \multicolumn{2}{|c|}{$7 \%$ Grass and Forb Use } & \multicolumn{2}{|c|}{$11 \%$ Grass and Forb Use } & \multicolumn{2}{|c|}{$15 \%$ Grass and Forb Use } \\
\hline & & $7 \%$ Shrub & $60 \%$ Shrub & $11 \%$ Shrub & $60 \%$ Shrub & $15 \%$ Shrub & $60 \%$ Shrub \\
\hline \# animals & 959 & 972 & 1260 & 2039 & 3268 & 2976 & 5275 \\
\hline Density/ha & 0.07 & 0.07 & 0.09 & 0.15 & 0.24 & 0.22 & 0.39 \\
\hline Bison & 476 & 174 & 174 & 265 & 174 & 374 & 174 \\
\hline Moose & 72 & 24 & 492 & 0 & 792 & 0 & 1092 \\
\hline Wapiti & $333^{*}$ & 348 & 348 & 348 & 348 & 348 & 348 \\
\hline Deer & 78 & 425 & 246 & 1425 & 1953 & 2254 & 3660 \\
\hline
\end{tabular}

*Wapiti numbers in 2006 were below their Minimum Viable Population. 


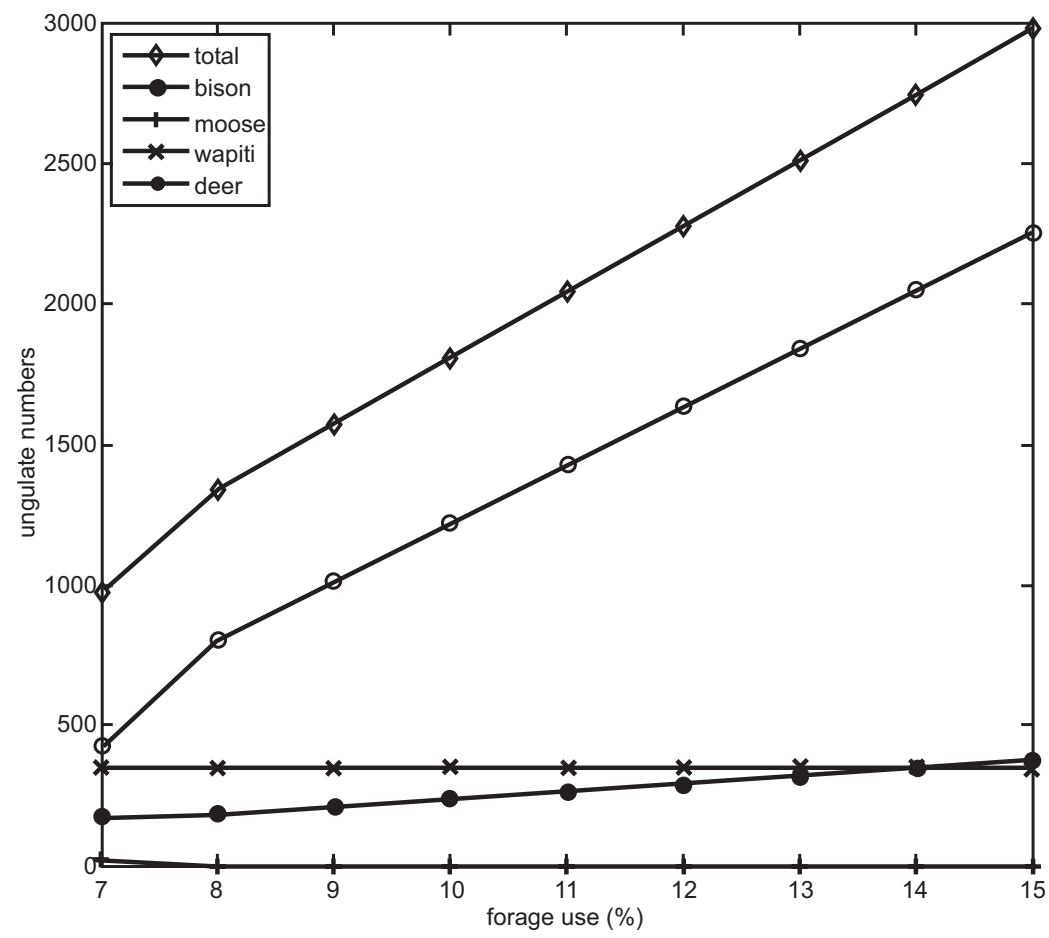

Fig. (3). Results from the forage allocation model to maximize animal numbers in Elk Island National Park. Ungulate numbers are shown for all and each species separately. For all forage usages, wapiti remain at their minimum viable population level, with bison and deer increasing with increasing forage. Moose are only present for a narrow range of forage usage.

bison occupied the park in 2006, the predicted optimal combination was 425 deer, 24 moose and 174 bison. Numbers of wapiti (333) were close to the predicted representation (348). When forage use was increased above $8 \%$, moose were not prescribed by the optimal solution because sufficient shrub forage was no longer available, wapiti numbers remained at the minimum population density, whereas bison and deer increased (Fig. 3). Under this scenario, the high contribution of deer to the total numbers of ungulates is expected as deer have the lowest mass of all species considered, which can be compensated for by increased animal numbers.

Qualitative changes in the solutions were found as a function of forage use (Fig. 3). For forage use at 7\%, bison were above the minimum viable population size, whereas wapiti were at their minimum density. For higher forage use ( $8 \%$ or more), moose were eliminated, wapiti remained at the minimum, and deer and bison numbers were above each spe- cies' minimum and increased markedly with increasing forage use (Table 3; Fig. 3).

When shrub utilization was set at $60 \%$, with forb and grass forage use between 7 and $15 \%$, deer and moose dominated the system, with wapiti and bison remaining at their minimum viable numbers (Table 3 ). In the previous scenario when forage use for grass, forbs and shrubs were $7 \%$, there were 425 deer, 348 wapiti, 24 moose and 174 bison, which differed when grass and forbs were $7 \%$ and shrubs was $60 \%$, giving 246 deer and 492 moose, with the same number of wapiti and bison (Table 3; Fig. 3).

The model predicted a maximum ungulate biomass of $34.8 \mathrm{~kg} / \mathrm{ha}$ at $11 \%$ forage use (all forage classes) with a value similar to that in EINP $(33.5 \mathrm{~kg} / \mathrm{ha})$ in December 2006 . At $11 \%$ forage use, the model predicted densities of bison $(0.031 / \mathrm{ha})$, moose $(0.015 / \mathrm{ha})$, wapiti $(0.026 / \mathrm{ha})$ and deer

Table 4. Comparison of Maximum Ungulate Biomass of Elk Island National Park Stocking Rates (2006) with Model Predictions Based on Percentage (\%) Forage Use. Forage Use is Defined as Equivalent Ratios of Grass, Forbs, and Shrubs Except when Grass and Forbs were Equivalent and Shrubs were Set at $60 \%$

\begin{tabular}{|c|c|c|c|c|c|c|c|}
\hline & \multirow[b]{2}{*}{ EINP } & \multicolumn{2}{|c|}{$7 \%$ Grass and Forb Use } & \multicolumn{2}{|c|}{$11 \%$ Grass and Forb Use } & \multicolumn{2}{|c|}{$15 \%$ Grass and Forb Use } \\
\hline & & $7 \%$ Shrub & $60 \%$ Shrub & $11 \%$ Shrub & $60 \%$ Shrub & $15 \%$ Shrub & $60 \%$ Shrub \\
\hline $\mathrm{kg} / \mathrm{ha}$ & 33.5 & 21.9 & 35.2 & 34.8 & 56.3 & 47.6 & 77.5 \\
\hline Density/ha & 0.07 & 0.05 & 0.09 & 0.07 & 0.24 & 0.10 & 0.39 \\
\hline Bison/ha & 0.04 & 0.02 & 0.01 & 0.03 & 0.01 & 0.05 & 0.01 \\
\hline Moose/ha & 0.01 & 0.01 & 0.04 & 0.01 & 0.06 & 0.02 & 0.08 \\
\hline Wapiti/ha & 0.02 & 0.03 & 0.03 & 0.03 & 0.03 & 0.03 & 0.03 \\
\hline Deer/ha & 0.01 & 0.00 & 0.02 & 0.00 & 0.15 & 0.00 & 0.27 \\
\hline
\end{tabular}




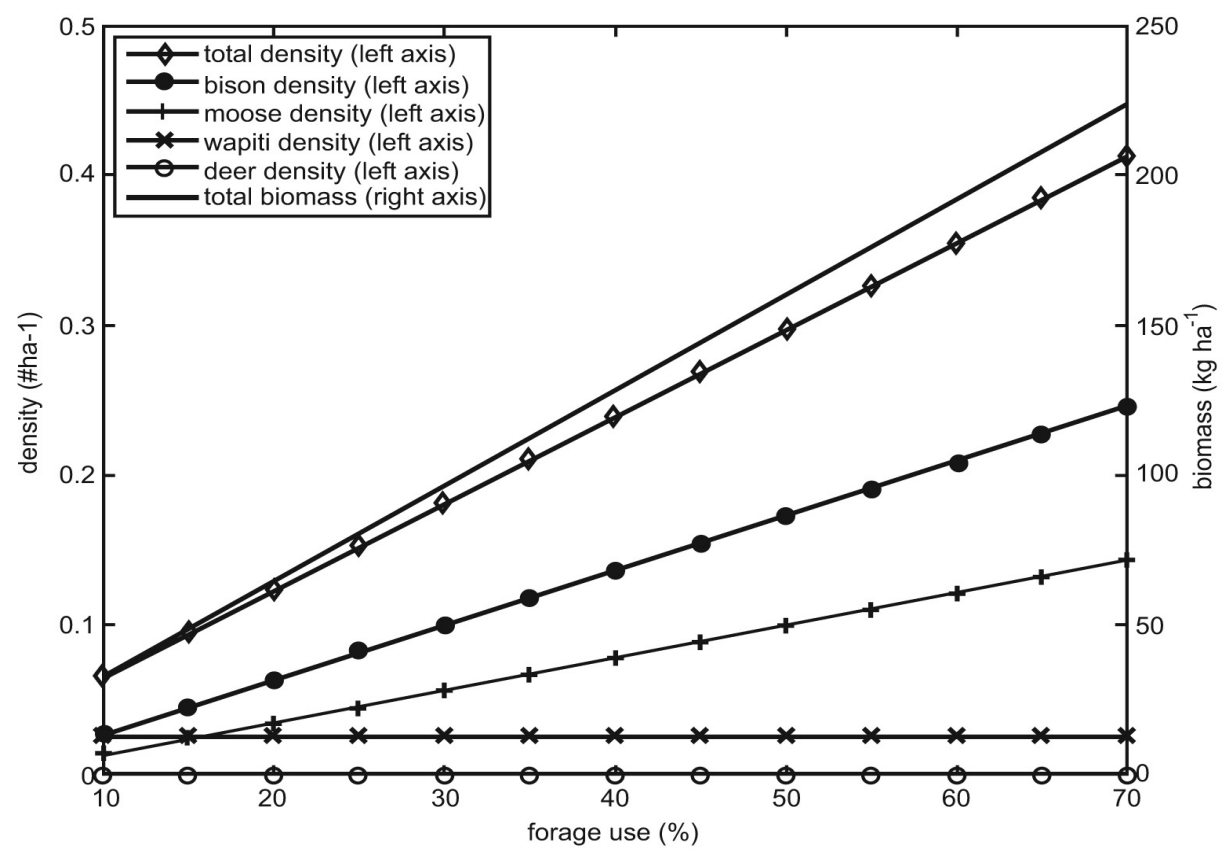

Fig. (4). Results from the forage allocation model to maximize biomass in Elk Island National Park, subject to the constraints of forage availability and minimum viable population densities for bison and wapiti. Ungulate densities and total biomass are shown for a range of percent forage use. Total density and total biomass increase with increasing forage use. Bison and moose densities also increase with forage use. Deer density is zero for all forage use whereas wapiti density remains at the minimum set by the minimum viable population constraint.

(0/ha) that differ from current EINP densities of bison $(0.036 / \mathrm{ha})$, moose $(0.005 / \mathrm{ha})$, wapiti $(0.025 / \mathrm{ha})$ and deer (0.006/ha) (Table 4).

When total forage use was $18 \%$ (ungulate biomass at $57.2 \mathrm{~kg} / \mathrm{ha}$ ) the solution was associated with bison and moose densities of $0.06 / \mathrm{ha}$ and $0.03 / \mathrm{ha}$ respectively, and at $25 \%$ (ungulate biomass at $79.6 \mathrm{~kg} / \mathrm{ha}$ ) with $0.08 \mathrm{bison} / \mathrm{ha}$ and $0.05 \mathrm{moose} / \mathrm{ha}$, while wapiti densities remained constant at the MVP (Fig. 4). Deer were not present in any optimal solutions from $10-70 \%$ forage use.

Setting maximum allowable shrub utilization to $60 \%$ and leaving grass and forbs at $7 \%$ forage use produced a total ungulate biomass of $35.2 \mathrm{~kg} / \mathrm{ha}$, which is similar to that present in EINP (33.5 kg/ha) in December 2006 (Table 4). When forage use of grass and forbs was set at $7-15 \%$ and shrubs at $60 \%$, optimal stocking combinations were dominated by deer and moose, with bison and wapiti at minimum viable population levels (Table 4).

Sensitivity analysis for $11 \%$ annual forage use across all forage types (which results in similar biomass and ungulate configuration as that observed in the park in December 2006) indicated that an increase of $1 \mathrm{~kg} / \mathrm{ha}$ of available grass and shrub forage would increase maximum ungulate biomass levels by 0.176 and $0.143 \mathrm{~kg} / \mathrm{ha}$, respectively. Given that 1 $\mathrm{kg} / \mathrm{ha}$ is distributed over the spatial extent of the study area $(13,400 \mathrm{ha})$, an increase of this magnitude represents an additional $2,358 \mathrm{~kg}$ of biomass, which is equivalent to about four additional bison. The constraint for available forbs was non-binding so increasing this forage component alone did not yield an increased ungulate biomass.

\section{DISCUSSION}

Estimates of mixed species carrying capacity that maximized ungulate numbers and maximum ungulate biomass were compared to recent (December 2006) ungulate counts in the park. By setting the annual proportion of forage used at $7-11 \%$, the model predicted ungulate densities comparable to those observed in the park in 2006. This is lower than allowable use levels recommended by others (e.g., 35-50\%) [22]. There may be several reasons for this discrepancy.

The aim of the study was to predict optimal combinations of ungulates so we compared model solutions with estimates of ungulate densities. Bison and wapiti densities are considered accurate as these species are contained by the fence, but there may have been more moose and deer in the park at other times of year, which would remove substantial amounts of vegetation. For example, during the December survey 476 bison and 333 wapiti but only 78 moose and 72 deer were counted, which may suggest trans-boundary movements of moose and deer and be reflected in the low forage use. The numerous lakes and ponds in the park $(10 \%$ of total area) may attract moose in the summer and they may stay there for part of the year. When herbage availability decreases in late fall, and wapiti switch to browse, moose may be displaced by the high density of wapiti [76]. Considering the behavioral disturbance from wapiti, it may be beneficial for moose to leave the Park, as there is ample forage in and near the agricultural fields, and no large predators. After plants senesce in late fall and certainly during the spring flush of new vegetation, deer and moose may move out of the park into the surrounding agricultural land to feed on agricultural crops. The breeding season may have some influence on trans-boundary movements of moose and deer. Moose generally rut in October, and moose that leave the Park during the rut, may not return until spring when the aquatic plants become available. And male deer may be more active in early December as it coincides with the end of the rutting season, and may spend time outside of the Park. 
The EINP ungulate survey was also based on pre-calving numbers, so forage removal by young-of-the-year ungulates would not be accounted for. We used forage intakes based on estimates gathered from experimental animals which were barren females and generally lighter than EINP animals. These factors may have lead to an underestimate of forage intake. In addition, the cost of lactation may increase forage intake by $50 \%$ [77]. But these measures are consistent with conventional animal-unit calculations that also ignore forage intake by calves or lactation of adult females [22].

Previous estimates of high biomass $(57.1 \mathrm{~kg} / \mathrm{ha})$ in EINP assumed intake of ungulates at $2.2 \mathrm{lb} / 100 \mathrm{lb}$ body mass [44]. When we set forage use at $18 \%$, model solutions were comparable to those estimates of high ungulate biomass [44]. Telfer and Scotter [44] however, did not include deer in their study. We included deer in the model, which may have accounted for greater overall forage removal and the disparity between the estimate reported here, and that reported by Telfer and Scotter [44].

The perimeter fence restricts movement of bison and wapiti, forcing them to subsist year-round on vegetation within the park. Both species are large-bodied and grass is predominant in their annual diet $(91 \%$ for bison; $50 \%$ for wapiti), which is unlikely to change even if their densities increase [78]. Grass intake was the main constraint preventing increased stocking rates. For example, this was shown by the low number of bison in the model output compared to the number of bison observed in the survey. This was illustrated by fixing shrub utilization to $60 \%$ [44] while leaving "forage use" set at lower levels; the combination of these limitations produced a system dominated by moose and deer, and resulted in bison and wapiti abundance equal to those densities previously established to represent the MVP.

The forage allocation approach does not explicitly account for forage quality and we assumed that forage quality does not limit intake. Forage quality models have been developed for mule deer [18], wapiti [79], mountain sheep [80], and white-tailed deer $[81,82]$. Forage biomass models can be comparable to nutritional-based models when forage quality is not limiting [82]. The advantage of the forage quantity approach is the limited data requirements. Although, we still did not have current annual vegetation biomass data or GIS habitat classification to compare with predicted ungulate combinations. Forage quality models still determine principle forage use from diet studies, but metabolizeable energy and nitrogen requirements need to be garnered from laboratory analysis. There are also still many assumptions that need to be made in forage quality models regarding nutritional requirements for each ungulate species [7].

Functional interactions of ungulates [83], changing vegetation succession [84-86], and dynamic feedback by ungulates to stimulate plant growth [87-89] were also not accommodated in this forage allocation approach. The park is generally available to all ungulates throughout the year (i.e., there are no seasonal migrations to other food sources). Bison and wapiti can show localized habitat separation in EINP [76] and competition between bison and mule deer is considered insignificant [7]. Mule deer can favor growth of grass by browsing competing shrubs and forbs [90]. Bison activity (wallowing, trampling) may have reduced the southern ex- pansion of aspen trees to the prairie [91], but the number of bison currently in the park has not reduced aspen encroachment.

Because less than $10 \%$ of park habitat contains a major component of graminoids, these areas can become heavily grazed and vegetation damaged by trampling [60,92]. Heavy herbivory has been tied to reductions in the structural diversity of forest and understory strata $[59,93,94]$, as well as replacement of native plant communities by less diverse communities dominated by introduced plant species $[60,95,96]$. If a large component of the herbivory is occurring in select areas of the park such as grasslands, then there may be an assumption that the entire park is being heavily grazed. Prescribed fire can alter plant communities and enhance grass biomass [59]. EINP's long-term goal for the prescribed fire program is to promote biological diversity and is not intended to increase production of grazers or browsers. A large wildfire in 2004 burned much of the Main Park. Because of this event, the prescribed fire program was put on hold for several years. It is anticipated that the program will be re-implemented in 2009, and may increase grassland habitats for bison and wapiti.

Solutions using shrub utilization of $60 \%$ and much lower fixed values for grass and forbs $(7-11 \%)$ produced a system dominated by moose and deer. Browse survey data from EINP shows that beaked hazel provides over $50 \%$ of the available browse and is very resilient to browsing, with 70$80 \%$ utilization common [97]. However, it is uncertain whether this use is sustainable, particularly when coupled with marked reductions in the abundance of other palatable shrubs such as Saskatoon, pincherry and chokecherry within the park [60].

Weathering could have accounted for substantial reduction of available forage biomass $[98,99]$ and may be a critical but unquantified factor in estimating carrying capacity on northern ranges. In southeast Alberta on ungrazed pastures, total over-winter weathering loss to available vegetation was up to $60 \%$, and also varied with forage class, whereby forbs could disappear almost completely while losses for grasses ranged between $27-52 \%[100,101]$. This is similar to an estimated over-winter weathering loss of $58 \%$ forage biomass at and near EINP [101]. Weathering loss is greatest after senescence, when vegetation becomes decumbent from snow loads [100]. The fragmented leaves and vegetative parts begin decomposition by weathering, leeching [99], photochemical processes [101] and microbial degradation $[102,103]$. Moisture, temperature and wind can enhance vegetation decomposition rates, as experiments monitoring cotton-rotting rates found high decomposition rates during wetter seasons and were associated with microhabitats such as wetter slopes [104].

The forage allocation approach used here does not explicitly account for diet quality restrictions, nor changes in biomass availability with depletion. The availability of seasonal biomass and nutritional quality are not monitored and the research necessary to turn these measures into an assessment of the nutritional adequacy is therefore incomplete. This problem is handled by allowing an additional reduction in the safe-use factors, which may reduce but not eliminate this risk. Ungulates select the most nutritious forage initially and use this selection opportunity as it is progressively de- 
pleted. Accounting for diet quality in the model would refine the outputs, but the labor, time, and expense required for gathering and processing the additional data would not be practical for most resource management studies. Our model outputs would have benefited from current forage biomass values, especially if they were gathered annually and averaged over several years to account for inter-annual variation in forage production.

For resource managers, impacts from ungulates on vegetation are becoming a common management problem [105109], while options for controlling ungulate populations by slaughter, translocation and reproductive control receive little public and/or government support [110]. Translocation receives the greatest level of public support, but disease concerns have reduced the safety of translocating wildlife [111114]. Along with the high costs of handling and management, resource managers have explored alternatives for vegetation management including prescribed burning [59] and intra-guild competition [43,58,115-117].

When the concept of carrying capacity was initially developed in wildlife and range management, estimates of forage removal by ungulates were commonly set at $50 \%$ under moderate grazing [2]. Recently, more conservative levels of forage removal are being considered in an attempt to account for abiotic factors such as droughts [24] and biotic factors such as trampling [22]. Some authors have suggested setting carrying capacity at $25 \%$ forage removal by the target ungulates, which would leave $25 \%$ for natural disappearance by other wildlife, insects, trampling and weathering and the remaining 50\% for site protection [22]. Although Irby et al. [20] created a forage allocation model for wild ungulates in a National Park in North Dakota and assumed 35\% forage use, they provided no results or discussion of total annual forage removal and thus avoided explaining implications for wild ungulates during one full year. In a detailed evaluation of stocking rates for livestock, Galt et al. [118] determined that measured forage use was consistently $10-15 \%$ greater than intended use.

In this study, weathering losses of forage may explain the apparently low predicted proportion of forage used by the four ungulate species. Reduced availability of forage due to weathering is rarely assumed as a separate category, and is normally pooled with other losses such as consumption by other wildlife species (including insects), and trampling. Under these assumptions, pooled losses in this category are generally assumed to be $25 \%$ combined [22]. The EINP study area contained about $10 \%$ standing water, and receives precipitation in the form of both rain and snow. Water is a key component in weathering loss to vegetation as it can increase decomposition rates through microbial action [98]. Snow pack can mechanically break vegetation, and during the spring melt the ground layer over a larger percent of the park may be moist, adding to decomposition rates [104]. In addition, because a large component of grasses and sedges sought by bison and wapiti are near water bodies, vegetation that is trampled may be exposed to moist soil, with increased susceptibility to decomposition. If annual weathering losses of grasses in Alberta are found to be near 50\% [101], or between $27-52 \%$ depending on grass species [99], then this loss should be taken into account for annual estimates where annual requirements of wildlife need to be met $[42,119,120]$.

\section{CONCLUSION}

Management decisions for wild ungulates are normally made on an annual basis [42]. Linear programming was used to allocate annual forage supply in a manner that maximized ungulate numbers or ungulate biomass appropriately constrained by forage availability, sustainable use, and minimum viable populations of bison and wapiti. This study provides a simple protocol and template for an initial estimate of economic carrying capacity and ungulate stocking combinations that can be subsequently refined in long-term adaptive management programs. Useful models for resource managers are those that are simple and focused on a specific problem [121]. Complex dynamic models of grazing systems can be impractical for resource managers, as they often require complex data and the services of the model developer. Using simple templates and widely available software, stocking levels and combinations in multi-species grazing systems can be applied by resource managers in long-term programs of adaptive management.

In this study we used a precise definition of economic carrying capacity [6] and a one-year time step to provide realistic management scenarios based on annual ungulate densities and their available resources. We estimated economic carrying capacity for an ungulate guild in a fenced protected area without predators. These conditions are not unique to EINP [122]. In some cases, protected areas are fenced in an effort to exclude predators [123,124], which can restrict movements of ungulates that normally migrate [125]. In the absence of predation-related mortality and emigration, mangers are obliged to give consideration as to whether or not a given landscape can sustain the population of animals that reside within its boundaries. Thus, EINP was an ideal site on which to undertake a study of economic carrying capacity.

This type of study was not without its limitations. Significant challenges exist with regard to acquiring data relevant to species-specific annual intake rates $[34,70]$ and the manner in which they are partitioned across forage types. In addition, good estimates of forage classification specific to the landscape of interest are required before estimates of economic carrying capacity can be calculated. These challenges are further complicated when one considers that each of these estimates are likely taken over differing time frames.

Despite these difficulties, we have developed an application that characterizes four ungulates in central Alberta. These templates can easily be applied to other systems with similar problems. For example, recent emphasis has been placed on implementing the concept of carrying capacity for long-term sustainability of rangelands $[126,127,128]$ and as a planning tool in large land-use initiatives. In addition, there are several recent studies on overabundant wild ungulates impacting vegetation $[5,129,130]$ but with only limited focus on carrying capacity $[20,119]$.

\section{ACKNOWLEDGEMENTS}

This research was supported by the Natural Sciences and Engineering Research Council of Canada through a Strategic Research Grant, an NSERC Collaborative Research Opportunity Grant and Mathematics of Information Technology and Complex Systems (CJB), and a University of Alberta Graduate Research Assistantship (GWK). Thanks to Olaf 
Jensen (Canadian Wildlife Service) for providing GIS support.

\section{REFERENCES}

[1] Leopold A. Game management. Charles Scribner's Sons: New York 1933.

[2] Stoddart LA, Smith AD. Range management. $2^{\text {nd }}$ ed. McGraw-Hill 1955.

[3] Beck JL, Peek JM, Strand EK. Estimates of elk summer range nutritional carrying capacity constrained by probabilities of habitat selection. J Wildl Manage 2006; 70: 283-294.

[4] Dimond WJ, Armstrong DP. Adaptive harvesting of source populations for translocation: A case study with New Zealand robins. Conserv Biol 2007; 21: 114-124.

[5] Morellet N, Gaillard JM, Hewison AJM, et al. Indicators of ecological change: new tools for managing populations of large herbivores. J Appl Ecol 2007; 44: 634-643.

[6] Caughley G. What is this thing called carrying capacity? In: Boyce MS, Hayden-Wings LD, Eds. North American Elk: Ecology, Behavior and Management. University of Wyoming Press 1979, pp. $2-8$.

[7] Demarais S, Krausmann PR, Eds. Ecology and management of large mammals in North America. Prentice-Hall Canada Inc.: Toronto 2000.

[8] Bai YG, Abouguendia Z, Redmann RE. Relationship between plant species diversity and grassland condition. J Range Manage 2000; 54: 177-183.

[9] Angassa A, Oba G. Relating long-term rainfall variability to cattle population dynamics in communal rangelands and a government ranch in southern Ethiopia. Agric Syst 2007; 94: 715-725.

[10] Cabezas S, Moreno S. An experimental study of translocation success and habitat improvement in wild rabbits. Anim Conserv 2007; 3: 340-348.

[11] Tepedino V, Bradley B, Griswold T. Might flowers of invasive plants increase native bee carrying capacity? Intimations from Capitol Reef National Park, Utah. Nat Areas J 2008; 28: 44-50.

[12] Morris DW, Mukherjee S. Can we measure carrying capacity with foraging behavior? Ecology 2000; 88: 597-604.

[13] McNab J. Carrying capacity and other slippery shibboleths. Wildl Soc Bull 1985; 13: 403-40.

[14] McCullough DR, Barret RH, Eds. Wildlife Populations. Elsivir Science Publishers: London, UK 2001.

[15] Varley N, Boyce MS. Adaptive management for reintroductions: Updating a wolf recovery model for Yellowstone National Park. Ecol Modell 2006; 193: 315-339.

[16] Stewart KM, Bowyer RT, Ruess RW, Dick BL, Kie JG. Herbivore optimization by North American elk: Consequences for theory and management. Wildl Monogr 2006; 167: 1-24.

[17] Vetter, S. Rangelands at equilibrium and non-equilibrium: recent developments in the debate. J Arid Environ 2005; 62: 321-341.

[18] Wallmo OC, Carpenter LH, Regelin WL, Gill RB, Baker DL. Evaluation of deer habitat on a nutritional basis. J Range Manage 1977; 30: 122-127.

[19] Halls LK, Ed. White-tailed Deer Ecology and Management. Stackpole Books: Harrisburg, PA 1984

[20] Irby LR, Norland JE, Westfall JA, Sullivan MA. Evaluation of a forage allocation model for Theodore Roosevelt National Park. J Environ Manage 2000; 64: 153-169.

[21] Willoughby MG, Stone C, Hincz C, Moisey D, Ehlert G, Lawrence D. Guide to range plant community types and carrying capacity for the dry and central mixedwood subregions in Alberta. Alberta Sustainable Resource Development, Public Lands and Forest Division, Publication Number T/103 2006.

[22] Holechek JL, Pieper RD, Herbel CH. Range Management: Principles and Practices. 5th ed. Pearson Education, Inc.: Upper Saddle River 2004.

[23] Stephenson TR, Van Ballenberghe V, Peek JM, MacCracken JG. Spatio-temporal constraints on moose habitat and carrying capacity in coastal Alaska: Vegetation succession and climate. Rangeland Ecol Manage 2006; 59: 359-372.

[24] McLeod SR. Is the concept of carrying capacity useful in variable environments? Oikos 1997; 79: 529-542.

[25] Traill LW, Bigalke RC. A presence-only habitat suitability model for large grazing African ungulates and its utility for wildlife management. Afr J Ecol 2007; 45: 347-354.
[26] Owen-Smith N, Mills MGL. Predator-prey size relationships in an African large-mammal food web. J Animal Ecol 2008; 77:173-183. Van Soest. Nutritional ecology of the ruminant. 2nd ed. Cornell University Press: Amazon 1994.

[28] Codron D, Lee-Thorp JA, Sponheimer M, Codron J. Nutritional content of savanna plant foods: implications for browser/grazer models of ungulate diversification. Eur J Wildl Res 2007; 53: 100111 .

[29] Wiegmann SM, Waller DM. Fifty years of change in northern upland forest understories: Identity and traits of "winner" and "loser" plant species. Biol Conserv 2006; 129: 109-123

[30] Zimmerman TJ, Jenks JA, Leslie Jr. DM. Gastrointestinal morphology of female white-tailed and mule deer: Effects of fire, reproduction, and feeding type. J Mammal 2006; 87: 598-605.

[31] Torstenson WLF, Mosley JC, Brewer, TK, Tess MW, Knight, JE. Elk, mule deer, and cattle foraging relationships on foothill and mountain rangeland. Rangeland Ecol Manage 2006; 59 1: 80-87.

[32] Society for Range Management. Glossary of Terms in Range Management. 4th ed. Glossary Update Task Group (Ed.).; Denver, CO: Edison Press 1998.

[33] Patton BD, Dong X, Nyren PE, Nyren A. Effects of grazing intensity, precipitation, and temperature on forage production. Rangeland Ecol Manage 2007; 60: 656-665.

[34] Kuzyk GW, Hudson RJ. Animal-unit equivalence of bison, wapiti and mule deer in the aspen parkland of Alberta. Can J Zool 2007; 85: 767-773.

[35] Spalton JA. The food supply of Arabian oryx (Oryx leucoryx) in the desert of Oman. J Zool 1999; 248: 433-441.

[36] Owen-Smith N. A metaphysiological modeling approach to stability in herbivore-vegetation systems. Ecol Modell 2002; 149: 153178.

[37] Hernandez L, Laundre JW. Foraging in the 'landscape of fear' and its implications for habitat use and diet quality of elk Cervus elaphus and bison Bison bison. Wildl Biol 2005; 11: 215-220.

[38] Wallis De Vries M. Large herbivores and the design of large-scale nature reserves in western Europe. Conserv Biol 9 1995: 25-33.

[39] Wegge P, Shrestha AK, Moe SR. Dry season diets of sympatric ungulates in lowland Nepal: competition and facilitation in alluvial tall grasslands. Ecol Res 2006; 21: 698-706.

[40] Jenkins DA, Schaefer JA, Rosatte R, Bellhouse T, Hamr J, Mallory FF. Winter resource selection of reintroduced elk and sympatric white-tailed deer at multiple spatial scales. J Mammal 2007; 88: 614-624.

[41] Yoshihara Y, Ito TY, Lhagvasuren B, Takatsuki S. A comparison of food resources used by Mongolian gazelled and sympatric livestock in three areas in Mongolia. J Arid Environ 2008; 72: 48-55.

[42] Kuzyk, GW. Carrying capacity of sympatric ungulates in central Alberta. PhD Thesis, University of Alberta 2008.

[43] Blyth, CB. Dynamics of ungulate populations in Elk Island National Park. MSc Thesis, University of Alberta 1995.

[44] Telfer ES, Scotter GW. Potential for game ranching in boreal aspen forests of western Canada. J Range Manage 1975; 28: 172-180.

[45] Cairns AL, Telfer E. Habitat use by 4 sympatric ungulates in boreal mixedwood forest. J Wildl Manage 1980; 44: 849-857.

[46] Glover MD, Conner JR. A model for selecting optimal combinations of livestock and deer lease-hunting enterprises. Wildl Soc Bull 1988; 16: 158-163.

[47] Forchhammer MC, Boomsma JJ. Foraging strategies and seasonal diet optimization of muskoxen in west Greenland. 1995; Oecologia 104: 169-180.

[48] Van Dyne GM. Application and integration of multiple linear regression and linear programming in renewable resource analyses. $\mathrm{J}$ Range Manage 1966; 19: 356-362.

[49] Hudson RJ, Blyth C. Mixed grazing systems of the aspen boreal forest. In: International Rangeland Congress, Adelaide: Australia 1986; pp. 380-3.

[50] Hastings A, Hall R, Taylor CM. A simple approach to optimal control of invasive species. Theor Popul Biol 2006; 70: 431-435.

[51] Belovsky GE. Diet optimization by a generalist herbivore: the moose. Theor Popul Biol 1978; 14: 105-134.

[52] Hughes RN Ed. Behavioral mechanisms of food selection. NATO ASI series Vol. G 20, pp. 395-413. Springer-Verlag, Berlin 1990.

[53] Environment Canada [homepage on the internet]. Canadian Climate Normals 1971-2000. [updated 2005 April ] Available from <http://www.climate.weatheroffice.ec.gc.ca/climate_normals.html. 
[54] Cool N. Elk Island National Park Ungulate Reduction Report. Unpublished report, Parks Canada 2006.

[55] Wilson GA, Zitlau K. Management strategies for minimizing the loss of genetic diversity in wood bison and plains bison populations at Elk Island National Park. Unpublished report, Parks Canada 2003.

[56] Hood GA, Neufeld T. First record of mountain lions, Puma concolor, in Elk Island National Park, Alberta. Can Field-Nat 2004 118: 605-607.

[57] Hood GA, Bayley SE, Olson W. Effects of prescribed fire on habitat of beaver (Castor canadensis) in Elk Island National Park, Canada. Forest Ecol Manage 2007; 239: 200-209.

[58] Blyth CB, Hudson RJ. A plan for the management of vegetation and ungulates, Elk Island National Park. Elk Island National Park and University of Alberta: Edmonton, AB 1987.

[59] Bork EW, Hudson RJ, Bailey AW. Populus forest characterization in Elk Island National Park relative to herbivory, prescribed fire, and topography. Can J Bot 1997a; 75: 1518-1526.

[60] Bork EW, Hudson RJ, Bailey AW. Upland plant community classification in Elk Island National Park, Alberta, Canada, using disturbance history and physical site factors. Plant Ecol 1997b; 130: 171190

[61] Bork EW, Thomas T, McDougall, B. Herbage response to precipitation in central Alberta boreal grasslands. J Range Manage 2001; 54: $243-248$.

[62] Best JN, Bork EW. Aspen understory community classification in Elk Island National Park using environmental and overstory characteristics. Unpublished report, Parks Canada 2004

[63] Alberta Sustainable Resource Development [home page on the internet]. Methodology for calculating carrying capacity and grazing capacity on public rangelands [updated 2004 May 11]. Available from: http://www.srd.gov.ab.ca/lands/managingpublicland/rangemanagement/pdf/CC_GC_Methodology.pdf

[64] Holsworth WN. Interaction between moose, elk and buffalo in Elk Island National Park, Alberta. MSc Thesis, University of British Columbia 1960

[65] Cairns AL. Distribution and food habits of moose, wapiti, deer, bison and snowshoe hare in Elk Island National Park, Alberta. MSc Thesis, University of Calgary 1976.

[66] Renecker LA. Bioenergetics and behavior of moose (Alces alces) in the aspen-dominated boreal forest. Ph.D. Thesis, University of Alberta, Edmonton, AB1987a

[67] Renecker LA. Seasonal nutritional cycles of ungulates in Elk Island National Park. Report prepared for Elk Island National Park 1987b.

[68] Cool N. Physiological indices of winter condition of wapiti and moose. MSc Thesis, University of Alberta 1992.

[69] Dewitt P. Ungulate guild dynamics: mechanisms and consequences for aspen parklands. MSc Thesis, University of Alberta 2008.

[70] Kuzyk GW, Hudson RJ. Using $n$-alkane markers to estimate forage intake of mule deer. Can J Zool 2006; 84: 1576-1583.

[71] Renecker LA, Hudson RJ. Estimation of dry matter intake of freeranging moose. J Wildl Manage 1985; 49: 785-792.

[72] Hudson RJ, Drew KR, Baskin LM, Eds. Wildlife production systems: economic utilization of wild ungulates. Cambridge University Press: Renecker 1989

[73] Halls LK, Ed. White-tailed Deer: Ecology and Management, Harrisburg: Stackpole Books 1984.

[74] Harlow RF, Jones FK Jr., Eds. The white-tailed deer in Florida. Technical Bulletin 9. Tallahassee, Florida Game and Freshwater Fish Commission 1965.

[75] Visscher DR, Merrill EH, Fortin D, Frair JL. Estimating woody browse availability for ungulates at increasing snow depths. Forest Ecol Manage 2006; 222: 348-354

[76] Telfer ES, Cairns AL. Resource use by moose versus sympatric deer, wapiti and bison. Alces 1986; 22: 113-137.

[77] Gedir JV, Hudson RJ. Seasonal intake determination in reproductive wapiti hinds (Cervus elaphus canadensis) using $n$-alkane markers. Can J Anim Sci 2000; 80: 137-144.

[78] Singer FS, Norland JE. Niche relationships within a guild of ungulate species in Yellowstone National Park, Wyoming, following release from artificial controls. Can J Zool 1994; 72: 1383-1394.

[79] Hobbs NT, Baker DL, Ellis JE, Swift DM, Green RA. Energy- and nitrogen-based estimates of elk winter-range carrying capacity. J Wildl Manage 1982; 46:12-21.
[80] Mazaika R, Krauaman PR, Etchberger RC. Forage availability for mountain sheep in Pusch Ridge Wilderness, Arizona. Southwest Nat 1992; 37: 372-378.

[81] Potvin F, Huot J. Estimating carrying capacity of a white-tailed deer wintering area in Quebec. J Wildl Manage 1983; 49: 814-822.

[82] McCall TC, Brown RD, Bender LC. Comparison of techniques for determining the nutritional carrying capacity for white-tailed deer. J Range Manage 1997; 50: 33-38.

[83] Hobbs NT. Modification of ecosystems by ungulates. J Wildl Manage 1996; 60: 695-713.

[84] Knapp AK, Blair JM, Briggs JM, et al. The keystone role of bison in North American tall grass prairie. Bioscience 1999; 49: 39-50.

[85] Barrett MA, Stiling P. Effects of Key deer herbivory on forest communities in the lower Florida Keys. Biol Conserv 2006; 129:100-108

[86] Fuhlendorf SD, Engle DM. Restoring heterogeneity on rangelands: ecosystem management based on evolutionary grazing patterns. Bioscience 2001; 51: 625-632.

[87] Samson FB, Knopf FL, Ostlie WR. Great Plains ecosystems: past, present, and future. Wildl Soc Bull 2004; 32: 6-15.

[88] Martin LM, Wilsey BJ. Assessing grassland restoration success: relative roles of seed additions and native ungulate activities. J Appl Ecol 2006; 43: 1098-1109.

[89] Vazquez DP, Simberloff D. Indirect effects of an introduced ungulate on pollination and plant reproduction. Ecol Monogr 2006; 74: 281-308.

[90] Kay CE, Bartos DL. Ungulate herbivory on Utah aspen: Assessment of long-term exclosures. J Range Manage 2000; 53: 145-153.

[91] Campbell C, Campbell ID, McAndrews JH, Blyth CB. Bison extirpation may have caused aspen expansion in western Canada. Ecography 1994; 17: 360-363.

[92] Cumming DMH, Cumming GS. Ungulate community structure and ecological processes: body size, hoof area and trampling in African savannas. Oecologia 2003; 134: 560-568.

[93] Fornara DA, Du Toit JT. Browsing lawns? Responses of Acacia nigrescens to ungulate browsing in an African savanna. Ecology 2007; 88: 200-209.

[94] Manier DJ, Hobbs NT. Large herbivores in sagebrush steppe ecosystems: livestock and wild ungulates influence structure and function. Oecologia 2007; 152: 739-750.

[95] West NE. Biodiversity of rangelands. J Range Manage 1993; 46: 213 .

[96] Vavra M, Parks CG, Wisdom MJ. Biodiversity, exotic plant species, and herbivory: The good, the bad, and the ungulate. For Ecol Manage 2007; 246: 66-72.

[97] Best JN, Bork EW, Cool NL. Initial beaked hazel growth responses following protection from ungulate browsing. J Range Manage 2003; 56: 455-460.

[98] Hunt HW. A simulation model for decomposition in grasslands. Ecology 1977; 58: 425-433.

[99] Willms WD, King J, Dormaar JF. Weathering losses of forage species on the fescue grassland in southwestern Alberta. Can J Plant Sci 1998; 78: 265-272.

[100] Willms WD, Adams BW, Dormaar JF. Seasonal changes on aboveground biomass on the fescue prairie. J Range Manage 1996; 49:100-104.

[101] Donkor NT, Hudson RJ, Bork EW. Simulation and quantification of pasture condition and animal performance on boreal grasslands in Alberta. Agric Sys 2007; 93: 229-251.

[102] Moorehead DL, Reynolds JF. Mechanisms of surface litter mass loss in the northern Chihuahuan desert: a reinterpretation. J Arid Environ 1989; 16: 157-163.

[103] Holland EA, Coleman DC. Litter placement affects of microbial and organic matter dynamics in an agroecosystem. Ecology 1987; 68: 425-433.

[104] Risch AC, Jurgensen MF, Frank DA. Effects of grazing and soil micro-climate on decomposition rates in a spatio-temporally heterogeneous grassland. Plant Soil 2007; 298: 191-201.

[105] Decalesta DS. Effect of white-tailed deer on songbirds within managed forests in Pennsylvania. J Wild Manage 1994; 58: 711-718.

[106] Allombert S, Gaston AJ, Martin JL. A natural experiment on the impact of overabundant deer on songbird populations. Biol Conserv 2005; 126: 1-13.

[107] Anderson TM, Ritchie ME, McNaughton SJ. Rainfall and soils modify plant community response to grazing in Serengeti National Park. Ecology 2007; 88: 1191-1201 
[108] Johnston DB, Cooper DJ, Hobbs NT. Elk browsing increases aboveground growth of water-stressed willows by modifying plant architecture. Oecologia 2007; 154: 467-478.

[109] O'Connor TG, Goodman PS, Clegg B. A functional hypothesis of the threat of local extirpation of woody plant species by elephant in Africa. Biol Conserv 2007; 136: 329-345.

[110] Landman M, Kerley GIH, Schoeman DS. Relevance of elephant herbivory as a threat to Important Plants in the Addo Elephant National Park, South Africa. J Zool 2008; 274: 51-58.

[111] Gogan PJP, Barrett RH, Shook WW, Kucera TE. Control of ungulate numbers in a protected area. Wildl Soc Bull 2001; 29: 10751088 .

[112] Bellhouse T, Rosatte R. Assessment of the potential for negative interaction between re-introduced elk (Cervus elaphus) and resident white-tailed deer (Odocoileus virginianus) in their wintering areas in Ontario, Canada. Mammalia 2005; 69: 35-56.

[113] Brooks DR, Hoberg EP. Systematics and emerging infectious diseases: From management to solution. J Parasitol 2006; 92: 426429.

[114] Sibley JA, Woodbury MR, Appleyard GD, Elkin B. Mycobacterium avium subspecies paratuberculosis in bison (Bison bison) from Northern Canada. J Wildl Dis 2007; 43: 775-779.

[115] Petty AM, Werner PA, Lehmann CER, Riley JE, Banfai DS, Elliott LP. Savanna responses to feral buffalo in Kakadu National Park, Australia. Ecol Mongr 2007; 77: 441-463.

[116] du Toit JT, Yetman CA. Effects of body size on the diurnal activity budgets of African browsing ruminants. Oecologia 2005; 143: 317 325.

[117] Makhabu SW, Skarpe C, Hytteborn K, Mpofu ZD. The plant vigour hypothesis revisited - how is browsing by ungulates and elephant related to woody species growth rate? Plant Ecol 2006; 184 : 163-172.

[118] Galt DF, Molinar F, Navarro J, Joseph J, Holechek J. Grazing capacity and stocking rate. Rangelands 2000; 22: 7-11.
[119] Mysterud A. The concept of overgrazing and its role in management of large herbivores. Wildl Biol 2006; 12: 129-141.

[120] Steinheim G, Wegge P, Fjellstad JI, Jnawali SR, Weladji RB. Dry season diets and habitat use of sympatric Asian elephants (Elephas maximus) and greater one-horned rhinoceros (Rhinocerus unicornis) in Nepal. J Zool 2005; 265: 377-385.

[121] Starfield AM. A pragmatic approach to modeling for wildlife management. J Wildl Manage 1996; 61: 261-270.

[122] Woodroffe, R., Ginsberg, J.R. Edge effects and the extinction of populations inside protected areas. Science 1998; 280: 2126-2128.

[123] Moseby KE, Read JL. The efficacy of feral cat, fox and rabbit exclusion fence designs for threatened species protection. Biol Conserv 2005; 127:429-437.

[124] Robley A, Purdey D, Johnston M, Lindeman M, Busana F, Long K. Experimental trials to determine effective fence designs for feral cat and fox exclusion. Ecol Manage Rest 2007; 8: 193-198.

[125] Berger J. The last mile: How to sustain long-distance migration in mammals. Conserv Biol 2004; 18: 320-331.

[126] Benjaminsen TA, Rohde R, Sjaastad E, Wisborg P, Lebert T. Land reform, range ecology, and carrying capacities in Namaqualand, South Africa. Ann Assoc Am Geog 2007; 96: 524-540.

[127] Brekke KA, Oksendal B, Stenseth NC. The effect of climate variations on the dynamics of pasture-livestock interactions under cooperative and noncooperative management. Proc Nat Acad Sci USA 2007; 104: 14730-14734.

[128] Hayward MW, O’Brien J, Kirley GIH. Carrying capacity of large African predators: Predictions and tests. Biol Conserv 2007, 139: 219-229.

[129] Côté SD, Rooney TP, Tremblay JP, Dussault C, Waller DM. Ecological impacts of deer overabundance. Ann Rev Ecol Evol Sys 2004; 35: 113-147.

[130] Bradford JB, Hobbs NT. Regulating overabundant ungulate populations: An example for elk in Rocky Mountain National Park, Colorado. J Environ Manage 2008, 86: 520-528.

Received: November 24, 2008 Revised: February 27, 2009 Accepted: March 02, 2009

(C) Kuzyk et al.; Licensee Bentham Open.

This is an open access article licensed under the terms of the Creative Commons Attribution Non-Commercial License (http://creativecommons.org/licenses/by-nc/3.0/) which permits unrestricted, non-commercial use, distribution and reproduction in any medium, provided the work is properly cited. 